\title{
Spatio-Temporal Dynamics of Land Degradation in Rural Areas of Thar Desert of India
}

\author{
Mahesh Kumar Gaur*, Mahesh Kumar, J.S. Chauhan, Ashish Mishra, \\ Suraj Ismail Sheikh Pragya Mehrishi and Prachi Goyal \\ ICAR-Central Arid Zone Research Institute, Jodhpur, India \\ *Corresponding author
}

\begin{abstract}
A B S T R A C T
Keywords

IRS LISS III and LISS IV satellite data, GIS, Land degradation, Spatial distribution characteristics and assessment

Article Info

Accepted:

12 November 2020

Available Online:

10 December 2020

All living beings directly or indirectly are threatened by land degradation which is identified as a significant hampering agent for the justifiable development of the economy and societies. Sirohi district, which lies on the Aravalli hills, has been selected to study the spatiotemporal dynamics of land degradation, so as to understand the main contributing factors for its origin. Three season FCC of Resources at LISS III for the 2015-16 period has been used. The Geographic Information System (GIS) is an important tool for the appraisal of the amount of land degradation and its dynamics. Three types of land degradation i.e. severe, moderate and slightly degraded has been mapped, and normal areas without any degradation have also been identified. Waterborne erosion contributes about $20 \%$ area under degradation affecting $12-15 \%$ villages. The slightly-degraded area occupies for $10-12 \%$, the severely-degraded area covers $6-8 \%$ and the moderatelydegraded area occupies $2-5 \%$ of the entire geographic area. Northwestern area of the district is drained by the Luni River where areas affected by moderate to severe degradation is distributed.Administratively, the slight to moderately-degraded areas are primarily distributed in Sirohi, and Sheoganj whereas Pindwara and Reodar sub-divisions shows areas under moderate to severe degradation.
\end{abstract}

\section{Introduction}

Land degradation is identified as a hampering agent for the sustainable development of the economy and societies. All living beings directly or indirectly are threatened by it. It is also one of the major hazards to climate change and food security pliability of rural population around the globe. Over $20 \%$ of all agribusiness, $10 \%$ of the rangeland and $30 \%$ of forests suffer from degradation (Masto et al
2015; Bai et al., 2013; Jafari and Bakhshandehmehr 2013; Thomas et al., 2013). It influences poorer persons or families very badly as they lack the resources to compensate the loss of land productivity which is caused due to land impoverishment, food insecurity and nutritional fragility (Rao 2015; Izzo et al., 2013). It is important from the perspective of its probablemenace to land resources as well as the sustainability of human societies. Long-term human-induced 
pressure on vegetation coverage (Baeza et al 2007) and crop land (Kosmas et al., 2015; Santana et al 2010; Spanos et al., 2000), combined with abiotic factors such as high landform and climatic variability (ScarasciaMugnozza et al., 2000), create a varied and insecure environment.

Land degradation has been one of the prominent apprehensions of recent past for ensuring food security of the nation and acceleration in degradation proportion by population growth and unscientific utilization of resources result in impairing of carrying capacity of the land. Land degradation varies in process and magnitude across terrains (Gaur and Sharma 2003). Mining is another major anthropogenic destructive forms of land degradation affecting the health of terrestrial ecosystems. Per se, mining activity wields an enduring impact on the ecosystem, landscape, social, cultural and economic aspects. The pollution of water, air, land, soil quality, vegetation (including forest ecosystems), and human health and settlement has become a cause of serious concern due to on-going mining activities in the area. It also exposes the land to both wind and water erosion and other environmental vulnerabilities that pose threat to human beings in varied ways (Gaur and Gaur 2003). Therefore, protecting available land and water resources is essential for ensuring food security for the inhabitants of our country. Hence, the geospatial data plays an important role in providing essential information on land and water for conservation and planning. Differences in topography, soil characteristics, water availability, and land use all have an influence on the assessment of land degradation (Gaur and Sharma 2012).

The overall aim of present study is to apply a method to provide a reliable database with spatially explicit, up-to-date information on the condition of the land, the forces encouraging land degradation and the efficacy of management.

\section{Study area}

Sirohi district is located between $24^{\circ} 19^{\prime}$ $34.72^{\prime \prime}$ to $25^{\circ} 17^{\prime} 21.54^{\prime \prime}$ north latitude and $72^{\circ} 13^{\prime} 52.86^{\prime \prime}$ to $73^{\circ} 10^{\prime} 44.57^{\prime}$ ' east longitude which lies in the south-west part of Rajasthan. It occupies a total geographical area of $5139.1 \mathrm{~km}^{2}$ covering about $1.52 \%$ of the total area of Rajasthan. It is bounded by Pali district in the north-east, Jalore district in west, Udaipur district in the eastand Banaskantha district of Gujarat in the south (Fig. 1). The district has a well-developed drainage system, as three major river basins join parts of the district, viz. 'Luni River Basin' occupies a major part of the district and irrigates the northwestern part, the 'West Banas River Basin' is another important river in the basin and irrigates the southeastern part of the district and 'Sukri River Basin' flows southwestern part. Apart from these three, 'minor rivulets' and 'Sabarmati River Basin' also form small parts of the district. All these create a well-develop drainage system in the district. Except for hill ranges, the broad topographic elevation in the district is in the ranges of $250 \mathrm{~m}$ to $500 \mathrm{~m}$ above mean sea level. Elevation ranges from a minimum of $184.0 \mathrm{~m}$ above mean sea level in the NE part (Sheoganj block) of the district to a maximum of $1,689 \mathrm{~m}$ above mean sea level in the southern part (Abu Road block) of the district.

Aeolian, anthropogenic, denudational, fluvial and structural is the origin of various landform features (Table 1). Some areas in the northwest and southwestern part of the district are covered by alluvium and windblown sand. However, the major part of the district is under vast semi-desert plain. The soils are shallow to moderately deep in the hills whereas deep in the valley part. Medium textured soils are found in the west to 
southern part whereas light textured soils having yellowish brown exist occur in the north to the eastern part.

The rainfall is high in the central part of the district around the hills and decreases northwards and southwards from here. The general range of rainfall received in the year 2010 is from $900 \mathrm{~mm}$ to more than $1000 \mathrm{~mm}$ across the district. As per the land revenue record (2011), an area of $1372.16 \mathrm{~km}^{2}$ i.e. about $29.44 \%$ of the total reporting area, is under forest.

\section{Materials and Methods}

The materials required for mapping of land degradation classes are detailed below:

Satellite data: Multi-temporal ortho-rectified Resources at-2 LISS-III data of kharif, rabi and zaid seasons of 2015-2016 has been used for the delineation and updating of land degradation classes.

Ancillary data: Land use/ land cover maps derived from IRS LISS-III satellite data for the years 2005-06 and 2011-12 (LISS IV); land degradation mapping (Cycle 1) in 200506 from IRS LISS-III data; SRTM digital elevation models (DEMs) of 2007and wasteland mapping from IRS LISS-III data in 2008-09 and NDVI data from Sentinel-2 satellite scenes of 2015-17 provided the basis for the generation of present land degradation maps.

Ground truth Data: Ground data form an important source of information for mapping and accuracy estimation. Details were recorded along with information about the topography, position (latitude-longitude) and land cover of each field observation point.

A detailed classification into land use/ land cover classes was performed using multispectral indices and standard protocols set by the National Remote Sensing Center, Hyderabad (Fig. 2). The vector layers of CAZRI, Jodhpur and NBSSL\&UP has been used pertaining to soil series, order, land capability, etc.

Actually, land degradation is usuallya nonsequential (Scheffer et al., 2009) so it need to be understood within the local context (Warren, 2002). The most suitable land cover classification for classifying degradation has been determined by over-laying the earlier land degradation maps obtained from the interpretation of 2005-06 satellite imageries (Riva et al 2017). Field observations were conducted at selected locations to verify impact of land degradation. It was based on a predefined set of visual indicators of physical conditions to corroborate the land degradation maps (Table 2).

\section{Results and Discussion}

\section{Land use and degradation patterns}

The land use maps of 2005-06 and 2011-12 were analyzed using IRS LISS-II and LISSIV satellite data and statistics were generated (Table 3; Fig. 3 \& 4). It indicates that area under forest has tremendously increased from a mere $18.64 \%$ in $2005-06$ to $33.77 \%$ in 2011-12. It is due to the fact that there were below normal rainfall in 2005-06 causing a widespread drought-like situation in the district. The annual average rainfall is 868.6 $\mathrm{mm}$ based on the data of available years. The district received $995.45 \mathrm{~mm}$ rainfall in 2015 with a deviation of $14.6 \%$. The rain gauge station at Mount Abu (IMD) in district Sirohi had received one-day maximum rainfall of $444.6 \mathrm{~mm}$ on $27^{\text {th }}$ July 2015 followed by Aburoad in Sirohi district received $408 \mathrm{~mm}$ rainfall on $29^{\text {th }}$ July 2015. Except Mount Abu $(+111.58 \%)$ and Aburoad $(+65.44 \%)$, other stations had a negative trend of rainfall in the 
range of $-10.02 \%$ ( Sirohi) to $-44.75 \%$ (Sheoganj) and had a deficit or scanty rainfall.

It has also been seen that area under saltaffected increased appreciably in the district due to over-exploitation of underground saline to brackish water. It is the main cause of concern in the region. Similarly, the area under gullied and ravinous has also increased. Water is the main agent to instill this increase. Further, the constant pressure from an infrastructure developmental activities and needs of the teeming human population has caused a considerable decline in the agricultural activities. Some of the important grazing lands have either been transformed to agricultural fields or utilized for nonculturable purposes like schools, colleges, and hospitals as well as given on lease for mining of minerals to private parties. The area under mining has increased 10 times to 2005-06. It is clear from the table that there is an expansion of non-agricultural areas at the cost of agricultural areas. Areas around Mount $\mathrm{Abu}$ and piedmont zone are characterized by natural vegetation formations on fairly steep slopes and they are less affected by land use. They have experienced slight to moderate type of degradation due to its high altitude and to the improved humidity. The lower areas of the district, like Sheoganj, Pindwara, and Reodar blocks has a long history of land utilization, together with the shallow soils and steep slopes, have led to a reduced vegetation cover consisting of shrubland species. Furthermore, digging of soil for the supply of brick kilns is also one of the causes of degradation. There are around 32 such kilns located in Mandwa, Goeligaon, and Khamal villages.

Sirohi district is endowed with a number of minerals and limestone, calcite, wollastonite, masonry stone, granite, marble blocks are an important one. There are two large cement producing industries. It has been revealed during a field survey-cum-interaction with farmers by the author that the level of air pollution is quite high. Farmers reported that due to smoke and dust released by these industries ( cement and brick kiln), productivity has declined over a period of 1520 years. It has also been observed during ground truthing that vegetative coverage was cleared for firewood and charcoal making and overexploitation of vegetation is the second cause of soil degradation. Forest areas have been cleared.

\section{Livestock population and degradation patterns}

The livestock population has been on the increase except during the 1988 census (Fig 5). There were many casualties during the severe drought years of 1986-97 as well as people had disowned their animals in want of fodder. As such the present (2012) human:animal ratio in the district is 1.17 and livestock density is 175 animals $\mathrm{km}^{-2}$. It clearly points out to the pre-eminence of the livestock sector in the rural economy of arid western Rajasthan, and of the state as a whole. Table 3 indicates that grasslands in the district have declined from $1.10 \%$ in 2005-06 to $0.42 \%$ in $2011-12$. Sirohi breed of goat is quite hardy and can sustain local climatic fluctuations with ease. It browses so intensely and does not leave anything on the earth surface. Further, in spite of increasing trend of livestock population, grazing landscape is shrinking and biomass density and composition is very poor and badly degraded. Thus, providing poor quality and quantity of fodder. These long-term anthropogenic changes to the ecosystem have a major impact on soil and vegetation. The analysis indicates that degradation correlates the overgrazing since the onset of monsoon; second, with the increased number of animal movement, trampling of grasses occurred in the area; and third, with the decline in biomass and 
drinking water after November-December, animals migrate to Gujarat as a part of coping strategy. Overgrazing is the most prevalent source of land degradation, particularly around settlements, grazing lands, fallow lands and watering centers ( $\mathrm{HaO}$ and $\mathrm{Wu}$, 2006). Qualitative evidence collected through the discussion with the locals during the ground truthing suggest changes in soil and vegetation patterns.

\section{Landform, land use and degradation patterns}

Landform plays a major role in land use practices in the plains and areas close to the mountain range. This population growth rate (216,602 persons in 1931 and 1,036,346 persons in 2011 census) is quite high and the resulting fragmentation of land has severely drained land resources. It has caused considerable erosion of soil and additional pressure of land degradation. This increasing influence of land use change poses a threat to the conservation of soils in the low dissected hills and valleys and pediment-pediplain complex of denudational origin (Table 4). Even, land use changes have the potential of influencing the flow of surface runoff to the stream network and infiltration in the older alluvial and flood plains. Overgrazedor intensively cultivated land, due to inherent low infiltration capability, serve as source areas for overland flow in areas wherever it is unusual. Further, those landforms having high infiltration capability may act as safeguards by infiltrating surface runoff spawned straight on the upward slope. Rhyolites and Granites rocks, which represent Malani Igneous Suite (MIS), have substantial water retention capacity throughout the year. These rocks are exposed predominantly around Pindwara, Sirohi and Abu Road blocks (Sen and Nagori, 2016). Existence of groundwater is controlled by landform, relief and structural features both in the unconsolidated and consolidated saturated zone of formation (Table 5). Aquifers in phyllite and schists dominated landforms occur predominantly in Aburoad, Pindwara and central part of Sirohi tehsil. Groundwater is reserved in weathered zones and fractures joints. Depth to open wells collecting these aquifer ranges from 25 to 40 $\mathrm{m}$ (Sen and Nagori, 2016). There is year wise fluctuation in rainfall in Sirohi district which influences land utilization considerably in different landform zones.

There is an inverse relationship between the number of sources (20673 in 2006-07 and 22731 in 2014-15) and net area irrigated (95839 ha in 2006-07 and 75473 in 2014-15) in the district. It is amply clear that area under barren and un-culturable land has decreased as more and more area has been utilized for infrastructural developmental activities.

Land use capability classification predominantly shows the suitability of the soil for agriculture. It includes limitations imposed on the continued utilization of soils by the basic features of soils in combination with climate, relief, surface drainage, forest cover, erodibility and other natural hazards.

\section{Land capability classification and land degradation}

Soil and land productivity can be maintained through specified agri-management practices. The land is mostly used for agriculture and other activities of production. The land capability classification (LCC) acts as an important tool for the understanding capability for agricultural production on a permanent basis (Hudson 1971). Hence, the land capability is, by and large, determined by inherent soil characteristics features and environmental factors that restrict land-use. LCC II to III occupy $34.36 \%$ area of the district and can be labeled as land suitable for agriculture. The study indicated that $6.87 \%$ 
area of the total falls in the LCC II and total area of the LCC II (Fig 6). Similar kinds of limitations have been recognized for the second category of capability sub-class.The symbol given for each sub-class is used to the concerned land capability class as a suffix:

(a) Erosion and runoff (including the risk of erosion and post-erosion damage) -e,

(b) Excess of water (wetness, high watertable, the problem of drainage, overflow)-w,

(c) Root zone limitations (Shallow depth, low water holding capacity, salinity or alkalinity) s and

(d) Climatic limitations- c.

So, the II, III and IV categories have subclasses and are presented in fig. 6 to depict the relationship between degradation and LCC in the study area. These classes show the ground setting, extent and general suitability of the soils for agricultural use that are obtained at the capability class level. Soils in land class II have severe limitations for the use in agricultural activities. They are exposed to severe risks or damages. Soils orders Inceptisol and Entisol are dominant whereas Vertisol is predominant in IIs and IIw and Entisol in IIc. Loamy sand to sandy loam soil with coarse proper rotation of the crops is essential. Soils in this class have moderate steep slopes and are experience sever erosion. They are essentially low in fertility. The cover is required to protect soil from water erosion. It also helps to preserve soil structure.

Soils in land class III and IV occupy $27.49 \%$ and $20.65 \%$ respectively. These are shown by the addition of letters (e, w, c, s) where;

' $\mathrm{e}$ ' denotes erosion hazards (when the vulnerability of soil is the main problem in its use),

$*_{\mathrm{W}}$ ' denotes wetness (when an excess of water is the main problem),

' $c$ ' denotes climate ( when climate, e.g. temperature or lack of moisture is the main problem),

' $\mathrm{s}$ ' denotes soil within the sub-classes land capability units may be recognized (when limitations of the soil e.g. salinity are the main problems)

\section{Table.1 Origin-wise landform units in Sirohi District}

\begin{tabular}{|l|l|c|}
\hline Origin & & \% Area (to district total) \\
\hline \multirow{2}{*}{ Denudational } & Buried pediment & 46.32 \\
\cline { 2 - 2 } & Pediment & \\
\hline \multirow{2}{*}{ Hills } & Alluvial plain & 8.78 \\
\cline { 2 - 2 } & Valley fill & 8.51 \\
\cline { 2 - 3 } & Ravinous & 1.23 \\
\hline \multirow{2}{*}{ Aeolian Origin } & Denudational & 25.37 \\
\cline { 2 - 3 } & Structural & \\
\hline Anthropogenic & Linear Ridge & 7.37 \\
\hline Waterbodies & River, Pond, lake, canal, etc. & 0.48 \\
\hline
\end{tabular}


Table.2 Visual interpretation keys used for land degradation mapping

\begin{tabular}{|c|c|c|c|c|c|c|c|}
\hline $\begin{array}{l}\text { Land } \\
\text { degradation } \\
\text { process }\end{array}$ & $\begin{array}{c}\text { Land } \\
\text { degradation } \\
\text { type }\end{array}$ & Colour / Tone & $\begin{array}{c}\text { Texture } \\
\text { (on LISS-III } \\
\text { data) }\end{array}$ & Pattern & Size & Shape & Association \\
\hline \multirow[t]{4}{*}{$\begin{array}{l}\text { Water } \\
\text { erosion } \\
\text { (W) }\end{array}$} & $\begin{array}{l}\text { Sheet } \\
\text { erosion } \\
\text { (sh) }\end{array}$ & $\begin{array}{l}\text { Slightly brighter than } \\
\text { surrounding } \\
\text { land of its class }\end{array}$ & Smooth to medium & Contiguous patches & Small to large & Irregular & $\begin{array}{l}\text { Sloping cultivated /lands } \\
\text { with poor vegetal cover } \\
\text { during } \\
\text { rainy season. }\end{array}$ \\
\hline & Rills (ri) & $\begin{array}{l}\text { Brighter than surrounding land of } \\
\text { its class }\end{array}$ & Medium & $\begin{array}{l}\text { Discrete to } \\
\text { contiguous } \\
\text { patches }\end{array}$ & $\begin{array}{l}\text { Small to } \\
\text { medium }\end{array}$ & Irregular & Sloping cultivated lands. \\
\hline & Gullies $(\mathrm{gu})$ & $\begin{array}{l}\text { Brighter than surrounding land / } \\
\text { gray in color depending on soil } \\
\text { color }\end{array}$ & $\begin{array}{l}\text { Medium to slightly } \\
\text { coarse }\end{array}$ & $\begin{array}{l}\text { Discrete to } \\
\text { contiguous } \\
\text { patches }\end{array}$ & $\begin{array}{l}\text { Small to } \\
\text { medium }\end{array}$ & Irregular & First order streams. \\
\hline & $\begin{array}{l}\text { Ravines(rs } \\
\text { / rm) }\end{array}$ & Medium gray to dark gray & $\begin{array}{l}\text { Slightly coarse for } \\
\text { shallow ravines and } \\
\text { coarse for deep } \\
\text { ravines }\end{array}$ & Contiguous patches & $\begin{array}{l}\text { Large to very } \\
\text { large }\end{array}$ & Irregular & Stream / river banks \\
\hline \multirow[t]{4}{*}{$\begin{array}{l}\text { Wind erosion } \\
\text { (E) }\end{array}$} & $\begin{array}{l}\text { Sheet } \\
\text { erosion (sh) }\end{array}$ & $\begin{array}{l}\text { Various shades of yellow and } \\
\text { light } \\
\text { gray combination. }\end{array}$ & Smooth to medium & $\begin{array}{l}\text { Contiguous /mottling } \\
\text { (in cultivated areas) }\end{array}$ & $\begin{array}{l}\text { Large to very } \\
\text { large }\end{array}$ & $\begin{array}{l}\text { Regular / } \\
\text { Irregular }\end{array}$ & $\begin{array}{l}\text { Desertic plain areas with of } \\
\text { active sand movement }\end{array}$ \\
\hline & $\begin{array}{l}\text { Partially } \\
\text { stabilized } \\
\text { dunes (dp) }\end{array}$ & $\begin{array}{l}\text { Light grey to medium grey with } \\
\text { light yellowish tones. }\end{array}$ & Medium & $\begin{array}{l}\text { Contiguous /discrete } \\
\text { patches }\end{array}$ & $\begin{array}{l}\text { Small to } \\
\text { medium }\end{array}$ & $\begin{array}{l}\text { Regular / } \\
\text { Irregular }\end{array}$ & Desert sandy dunal area \\
\hline & $\begin{array}{l}\text { Stabilized } \\
\text { dunes (ds) }\end{array}$ & $\begin{array}{l}\text { Medium grey with light } \\
\text { yellowish tones during dry } \\
\text { season. Pink mottles during rainy } \\
\text { season. }\end{array}$ & Medium to coarse & Discrete patches & $\begin{array}{l}\text { Small to } \\
\text { medium }\end{array}$ & $\begin{array}{l}\text { Regular / } \\
\text { Irregular }\end{array}$ & Desert sandy dunal area \\
\hline & $\begin{array}{l}\text { Un- } \\
\text { stabilized } \\
\text { dunes }(\mathrm{du})\end{array}$ & $\begin{array}{l}\text { Various shades of yellow and } \\
\text { very } \\
\text { light gray combination. }\end{array}$ & Smooth to medium & $\begin{array}{l}\text { Contiguous / } \\
\text { discrete }\end{array}$ & $\begin{array}{l}\text { Medium to } \\
\text { large }\end{array}$ & Irregular & Desert sandy dunal area \\
\hline \multirow{2}{*}{$\begin{array}{l}\text { Water } \\
\text { logging } \\
\text { (L) }\end{array}$} & $\begin{array}{l}\text { Surface } \\
\text { ponding (sp) }\end{array}$ & Light blue to Very dark blue & Smooth & Discrete patches & $\begin{array}{l}\text { Small to } \\
\text { large }\end{array}$ & $\begin{array}{l}\text { Regular / } \\
\text { Irregular }\end{array}$ & $\begin{array}{l}\text { Depressions in inland } \\
\text { plains / coastal plains }\end{array}$ \\
\hline & $\begin{array}{l}\text { Sub-surface } \\
\text { water } \\
\text { logging (sw) }\end{array}$ & $\begin{array}{l}\text { Medium to dark gray on normal } \\
\text { FCC; on FCC with SWIR band } \\
\text { (R:G:B=SWIR:NIR:Red) various } \\
\text { shades of blue }\end{array}$ & Smooth & $\begin{array}{l}\text { Discrete/ contiguous } \\
\text { patches }\end{array}$ & $\begin{array}{l}\text { Medium to } \\
\text { large }\end{array}$ & Irregular & $\begin{array}{l}\text { In irrigated areas /plains } \\
\text { with high water table. }\end{array}$ \\
\hline
\end{tabular}


Int.J.Curr.Microbiol.App.Sci (2020) 9(12): 1553-1568

\begin{tabular}{|c|c|c|c|c|c|c|c|}
\hline $\begin{array}{l}\text { Land } \\
\text { degradation } \\
\text { process }\end{array}$ & $\begin{array}{c}\text { Land } \\
\text { degradation type }\end{array}$ & Colour / Tone & $\begin{array}{l}\text { Texture } \\
\text { (on LISS- } \\
\text { III } \\
\text { data) }\end{array}$ & Pattern & Size & Shape & Association \\
\hline \multirow[t]{3}{*}{$\begin{array}{l}\text { Salinisation / } \\
\text { Alkalisation } \\
\text { (S) }\end{array}$} & Saline (sa) & Light gray to white & Smooth & Discrete patches & $\begin{array}{l}\text { Small to } \\
\text { medium }\end{array}$ & Irregular & $\begin{array}{l}\text { Coastal plains/young alluvial } \\
\text { plains/stream courses/ irrigated } \\
\text { canal commands. }\end{array}$ \\
\hline & Sodic (so) & Grayish white / dull white & Smooth & Discrete patches & $\begin{array}{l}\text { Small to } \\
\text { medium }\end{array}$ & Irregular & $\begin{array}{l}\text { Older alluvial plains /stream } \\
\text { courses / irrigated canal } \\
\text { commands. }\end{array}$ \\
\hline & $\begin{array}{l}\text { Saline - Sodic } \\
\text { (ss) }\end{array}$ & Grayish white to White & Smooth & Discrete patches & Small to medium & Irregular & $\begin{array}{l}\text { Young to older alluvial / stream } \\
\text { courses / irrigated canal commands. }\end{array}$ \\
\hline $\begin{array}{l}\text { Acidification } \\
\text { (A) }\end{array}$ & Acidic (ac) & Various shades of green/ black & $\begin{array}{l}\text { Smooth to } \\
\text { medium }\end{array}$ & $\begin{array}{l}\text { Mottled / parceling, } \\
\text { contiguous /discrete }\end{array}$ & Small to large & Irregular & $\begin{array}{l}\text { Lateritic /high rainfall regions, } \\
\text { cultivated peats / marshes. }\end{array}$ \\
\hline Glacial (G) & $\begin{array}{l}\text { Frost heaving } \\
\text { (fh) }\end{array}$ & Light pink to grey & Smooth & $\begin{array}{l}\text { Discrete / contiguous } \\
\text { patches }\end{array}$ & Medium & $\begin{array}{l}\text { Regular / } \\
\text { Irregular }\end{array}$ & $\begin{array}{l}\text { Cultivated / fallow valley areas of } \\
\text { glacial region. }\end{array}$ \\
\hline \multirow[t]{3}{*}{$\begin{array}{l}\text { Anthropogen } \\
\text { ic } \\
\text { (H) }\end{array}$} & $\begin{array}{l}\text { Industrial- } \\
\text { effluent } \\
\text { affected areas } \\
\text { (ie) }\end{array}$ & $\begin{array}{l}\text { Various shades of blue, if } \\
\text { ponded with water. Light grey } \\
\text { to white patches when dries. }\end{array}$ & Smooth & $\begin{array}{l}\text { Discrete / } \\
\text { contiguous }\end{array}$ & $\begin{array}{l}\text { Small to } \\
\text { medium }\end{array}$ & $\begin{array}{l}\text { Irregular / } \\
\text { regular }\end{array}$ & $\begin{array}{l}\text { Adjacent to industries and its } \\
\text { effluent discharge pathways. }\end{array}$ \\
\hline & $\begin{array}{l}\text { Mining and } \\
\text { dump Areas } \\
\text { 9md) }\end{array}$ & $\begin{array}{l}\text { Shades of White, yellow, red, } \\
\text { black }\end{array}$ & $\begin{array}{l}\text { Smooth to } \\
\text { medium }\end{array}$ & Discrete & Small to medium & $\begin{array}{l}\text { Irregular / } \\
\text { regular }\end{array}$ & Hilly / plain areas. \\
\hline & $\begin{array}{l}\text { Brick kiln } \\
\text { (bk) }\end{array}$ & $\begin{array}{l}\text { Dull white to light } \\
\text { yellow }\end{array}$ & Smooth & $\begin{array}{l}\text { Isolated patches giving } \\
\text { rise to mottling pattern on } \\
\text { its background. }\end{array}$ & Very small & $\begin{array}{l}\text { Irregular / } \\
\text { regular }\end{array}$ & $\begin{array}{l}\text { Associated with urban areas and its } \\
\text { surroundings; located along } \\
\text { trafficable road network }\end{array}$ \\
\hline \multirow[t]{4}{*}{ Others (T) } & $\begin{array}{l}\text { Mass movement } \\
\text { /Mass wastage } \\
(\mathrm{mm})\end{array}$ & $\begin{array}{l}\text { Yellowish white to } \\
\text { very light cyan }\end{array}$ & Smooth & Discrete & $\begin{array}{l}\text { Very small to } \\
\text { small }\end{array}$ & $\begin{array}{l}\text { Irregular / } \\
\text { regular }\end{array}$ & $\begin{array}{l}\text { Foot of steep sloping } \\
\text { hilly regions }\end{array}$ \\
\hline & $\begin{array}{l}\text { Barren rocky/ } \\
\text { Stony waste (bs) }\end{array}$ & $\begin{array}{l}\text { Light to medium grey } \\
\text { /yellowish white }\end{array}$ & Smooth & $\begin{array}{l}\text { Discrete / } \\
\text { Contiguous }\end{array}$ & $\begin{array}{l}\text { Medium to } \\
\text { large }\end{array}$ & Irregular & Hilly or pediment regions \\
\hline & $\begin{array}{l}\text { Snow covered } \\
\text { areas }(\mathrm{sc})\end{array}$ & $\begin{array}{l}\text { Bright white to dull white; } \\
\text { bright blue on SWIR band } \\
\text { FCC (R:G:B=SWIR: } \\
\text { NIR:Red). }\end{array}$ & Smooth & $\begin{array}{l}\text { Contiguous } \\
\text { patches }\end{array}$ & $\begin{array}{l}\text { Large to } \\
\text { extensive }\end{array}$ & Irregular & $\begin{array}{l}\text { Very high altitude peaks \& } \\
\text { glaciers. }\end{array}$ \\
\hline & $\begin{array}{l}\text { Miscellaneous } \\
\text { (Riverine sands } \\
\text { / Sea ingress } \\
\text { areas, etc) (ms) }\end{array}$ & $\begin{array}{l}\text { Generally white. Light cyan } \\
\text { when associated with } \\
\text { Moisture }\end{array}$ & Smooth & $\begin{array}{l}\text { Discrete / } \\
\text { Contiguous }\end{array}$ & $\begin{array}{l}\text { Medium to } \\
\text { large }\end{array}$ & Irregular & $\begin{array}{l}\text { River banks / old river course/ } \\
\text { coastal beach/dune sands and river } \\
\text { bed/natural leeves }\end{array}$ \\
\hline
\end{tabular}

Source: Manual on Mapping of Land Degradation at 1:50,000 scale- 2nd Cycle (NRSC 2016) 
Table.3 Land use/ land cover during 2005-06 and 2011-12

\begin{tabular}{|l|r|l|r|}
\hline \multicolumn{1}{|c|}{$\begin{array}{c}\text { Land Use Classes (LISS-III) } \\
\text { (2005-06) }\end{array}$} & $\begin{array}{c}\text { Area } \\
\text { in \% }\end{array}$ & \multicolumn{1}{|c|}{$\begin{array}{c}\text { Land Use Classes (LISS-IV) } \\
(\mathbf{2 0 1 1 - 1 2 )}\end{array}$} & $\begin{array}{c}\text { Area } \\
\text { in \% }\end{array}$ \\
\hline Barren rocky & 2.45 & Barren rocky & 3.95 \\
\hline Crop land & 43.46 & Crop land & 37.88 \\
\hline Forest & 18.64 & Forest & 33.77 \\
\hline Forest Plantation & 0.46 & Forest Plantation & 0.01 \\
\hline Grass/ Grazing & 1.10 & Grass/ Grazing & 0.42 \\
\hline Gullied / Ravinous Land & 0.98 & Gullied / Ravinous Land & 1.23 \\
\hline River / Stream / canals & 2.14 & River / Stream / Drain & 2.10 \\
\hline Rural Settlement & 0.47 & Rural Settlement & 1.95 \\
\hline Sandy area & 0.86 & Sandy area & 0.46 \\
\hline Scrub land & 27.86 & Scrub land & 15.35 \\
\hline Urban Settlement & 0.40 & Urban Settlement & 0.67 \\
\hline Water bodies & 0.92 & Water bodies & 0.58 \\
\hline Mining/ industrial & 0.03 & Mining / industrial & 0.30 \\
\hline Salt Affected Land & 0.18 & Salt Affected land & 0.74 \\
\hline Inland Wetland & 0.03 & Lakes / Ponds & 0.46 \\
\hline
\end{tabular}

Table.4 Land use wise distribution of degraded lands in Sirohi district

\begin{tabular}{|l|l|c|}
\hline \multicolumn{1}{|c|}{ Land use } & \multicolumn{1}{|c|}{ Type of degradation } & Percentage area (\%) \\
\hline \multirow{2}{*}{ Agriculture } & Water erosion & 16.85 \\
\cline { 2 - 3 } Forest & Wind erosion & 0.011 \\
\hline \multirow{2}{*}{ Total Degraded land } & Water erosion & 8.43 \\
\hline & Wind erosion & 0.013 \\
\cline { 2 - 3 } & Salt affliction & 1.85 \\
\cline { 2 - 3 } & Stony/rocky waste & 14.8 \\
\cline { 2 - 3 } & Industrial effluent & 0.06 \\
\hline
\end{tabular}

Table.5 Land use-wise distribution of physiographic units

\begin{tabular}{|c|c|c|c|c|c|c|c|}
\hline Physiographic Units & 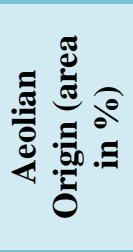 & 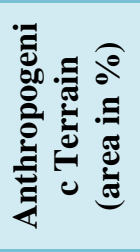 & 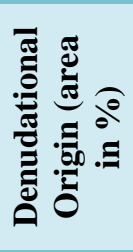 & 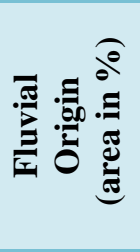 & 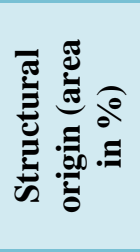 & 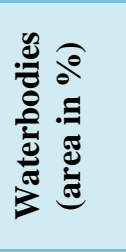 & 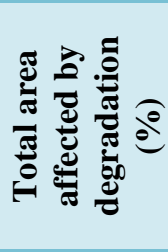 \\
\hline Crop land & 4.90 & 0.17 & 0.07 & 0.02 & 1.88 & 0.39 & 7.43 \\
\hline Forest & 0.06 & 0.01 & 7.54 & 9.50 & 20.33 & 0.07 & 37.50 \\
\hline Grass/ Grazing & 0.05 & 0.00 & 0.14 & 5.77 & 0.00 & 0.004 & 5.97 \\
\hline Barren rocky & 0.02 & 0.01 & 2.08 & 0.004 & 1.75 & 0.02 & 3.89 \\
\hline Gullied / Ravinous Land & 0.90 & 0.00 & 0.23 & 0.22 & 0.01 & 0.014 & 1.36 \\
\hline Mining / industrial & 0.005 & 0.05 & 0.16 & 0.11 & 0.05 & 0.001 & 0.38 \\
\hline Salt Affected & 0.01 & 0.00 & 0.48 & 0.92 & 0.00 & 0.001 & 1.41 \\
\hline Sandy area & 0.22 & 0.00 & 0.20 & 0.25 & 0.00 & 0.015 & 0.69 \\
\hline Scrub land & 0.72 & 0.05 & 10.57 & 0.94 & 1.16 & 0.21 & 13.65 \\
\hline Waterbodies & 0.08 & 0.18 & 0.46 & 0.65 & 0.16 & 1.21 & 2.74 \\
\hline
\end{tabular}


Table.6 Number of sources of irrigation and net area irrigated

\begin{tabular}{|l|c|c|c|c|c|}
\hline \multirow{2}{*}{ Year } & \multicolumn{2}{|c|}{ Wells } & Tanks & $\begin{array}{c}\text { Total number } \\
\text { of sources }\end{array}$ & $\begin{array}{c}\text { Net area } \\
\text { irrigated (ha.) }\end{array}$ \\
\cline { 2 - 6 } & Tubewells & Open wells & & 22731 & 75473 \\
\hline $\mathbf{2 0 1 4 - 1 5}$ & 1066 & 21620 & 45 & 22425 & 95274 \\
\hline $\mathbf{2 0 1 1 - 1 2}$ & 826 & 21555 & 44 & 20673 & 95839 \\
\hline $\mathbf{2 0 0 6 - 0 7}$ & 220 & 20409 & 44 & \\
\hline
\end{tabular}

Source: Agricultural Statistics, Government of Rajasthan

Table.7 Characteristics of soils

\begin{tabular}{|c|c|c|c|c|c|c|c|c|c|}
\hline Soil Texture & pH & EC & OC \% & $\begin{array}{c}\mathbf{C a C O}_{\mathbf{3}} \\
(\mathbf{\%})\end{array}$ & $\mathbf{C E C}$ & ESP & $\begin{array}{c}\text { Sand } \\
\text { \% }\end{array}$ & Silt \% & Clay \% \\
\hline Clay Soil & $7.8-8.0$ & $0.14-0.32$ & $0.16-0.21$ & $0.5-10$ & $7.25-18.5$ & $3.34-26.4$ & $30-60$ & $12-40$ & $22-48$ \\
\hline Fine sand & $8.3-8.6$ & $0.11-0.24$ & $0.06-0.20$ & $0.0-0.6$ & $2.3-7.2$ & $7.8-25.6$ & $90-99$ & $1.0-1.8$ & $2.5-9.0$ \\
\hline Loam & $7.9-8.6$ & $0.14-0.60$ & $0.20-0.31$ & $1.5-4.0$ & $5.9-19.7$ & $3.6-15.5$ & $65-85$ & $6-25$ & $5-20$ \\
\hline Loamy sand & $8.0-8.4$ & $0.20-0.78$ & $0.10-0.57$ & $0.0-0.37$ & $6.5-8.9$ & $1.9-35.5$ & $55-88$ & $6-20$ & $6-28$ \\
\hline Sandy loam & $7.5-8.6$ & $0.20-0.70$ & $0.04-0.60$ & $0.36-13.5$ & $7.1-12.9$ & $6.0-25.3$ & $55-85$ & $6.0-19.0$ & $6.0-27.0$ \\
\hline Silt loam & 7.9 & 0.48 & 0.2 & 2.5 & 7.4 & 8.1 & $52-55$ & $22-27$ & $19-20$ \\
\hline
\end{tabular}

Fig.1 Study area

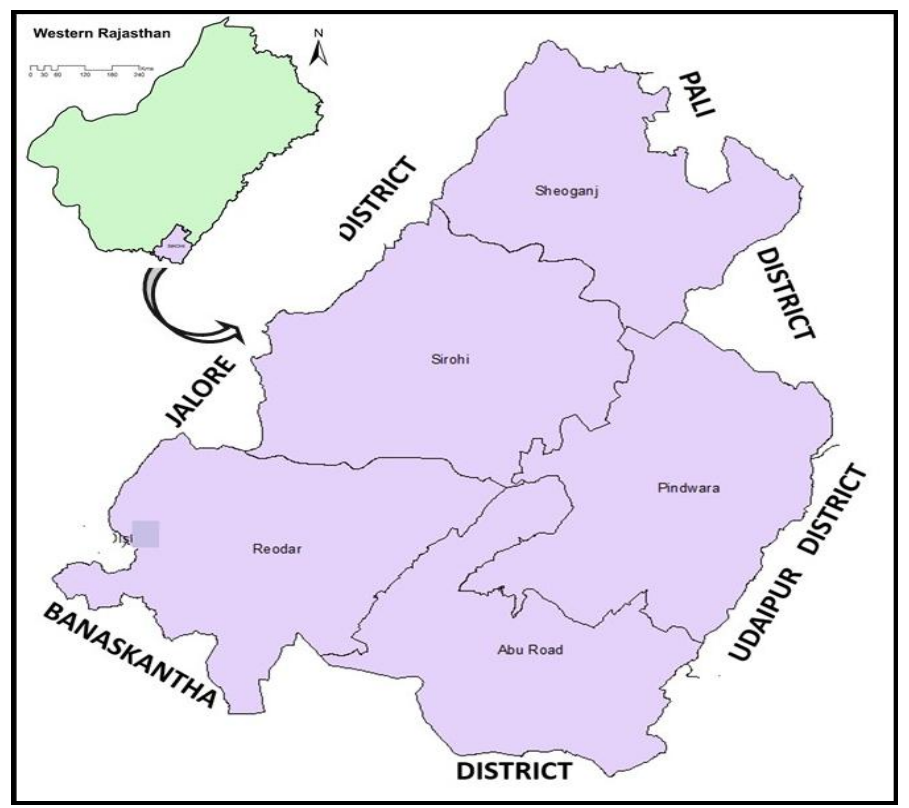


Fig.2 Approach for land degradation mapping

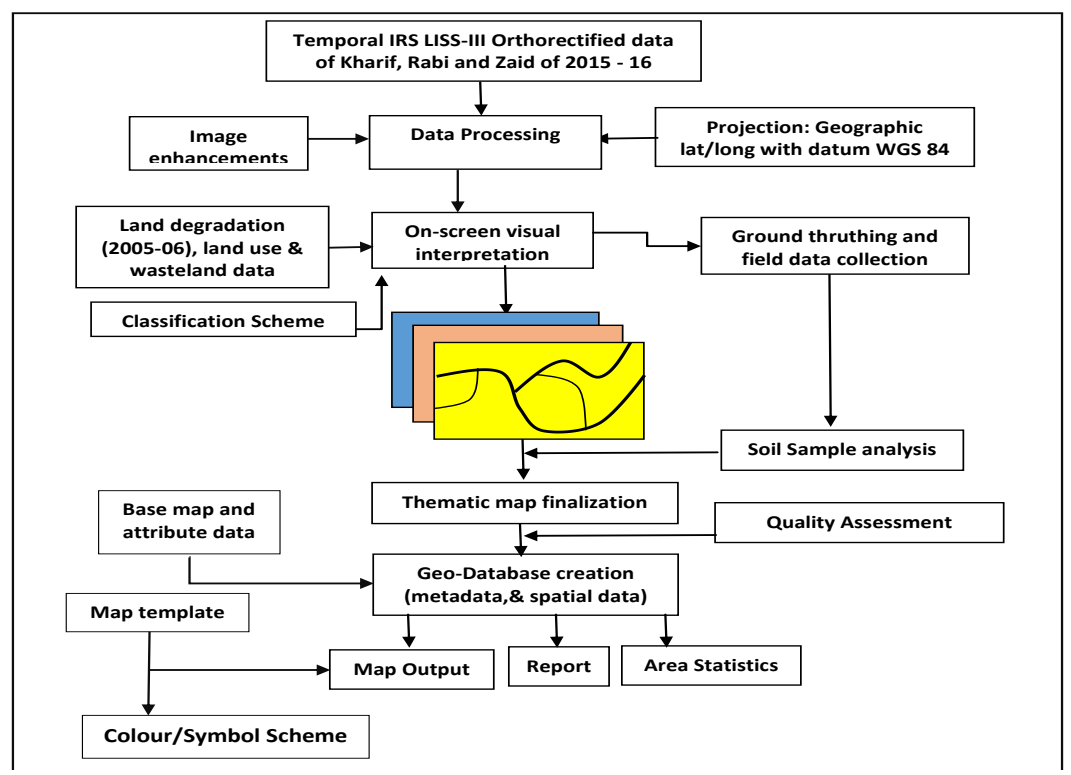

Fig.3 Land use/land cover map 2005-06 Fig.4 Land use/land cover map 2011-12

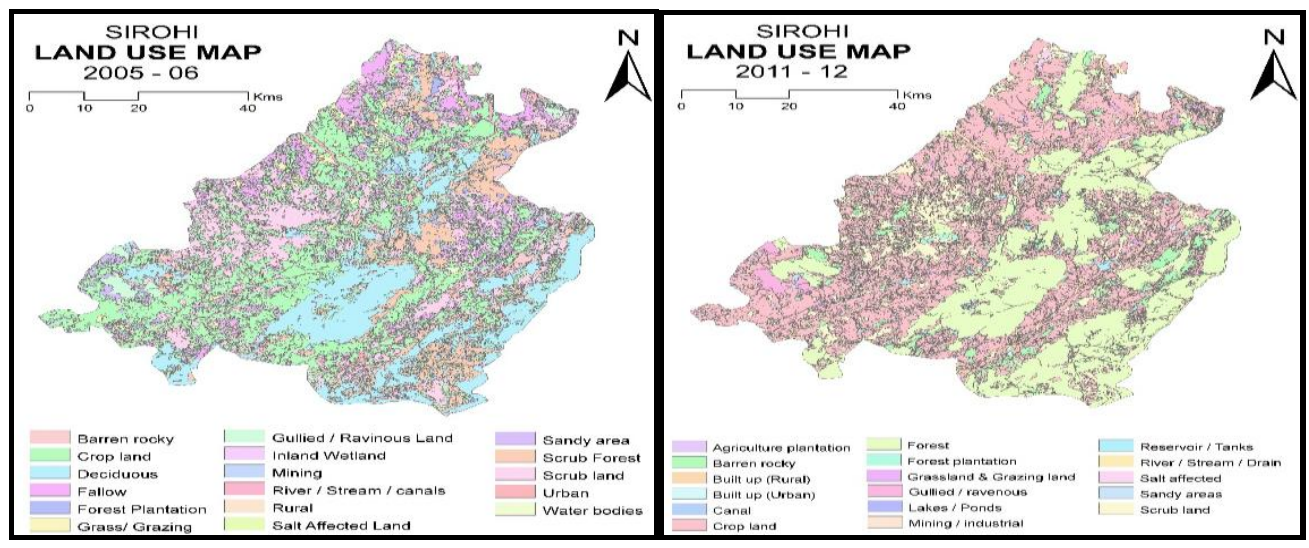

Fig.5 Livestock population in Sirohi district (1956 - 2012)

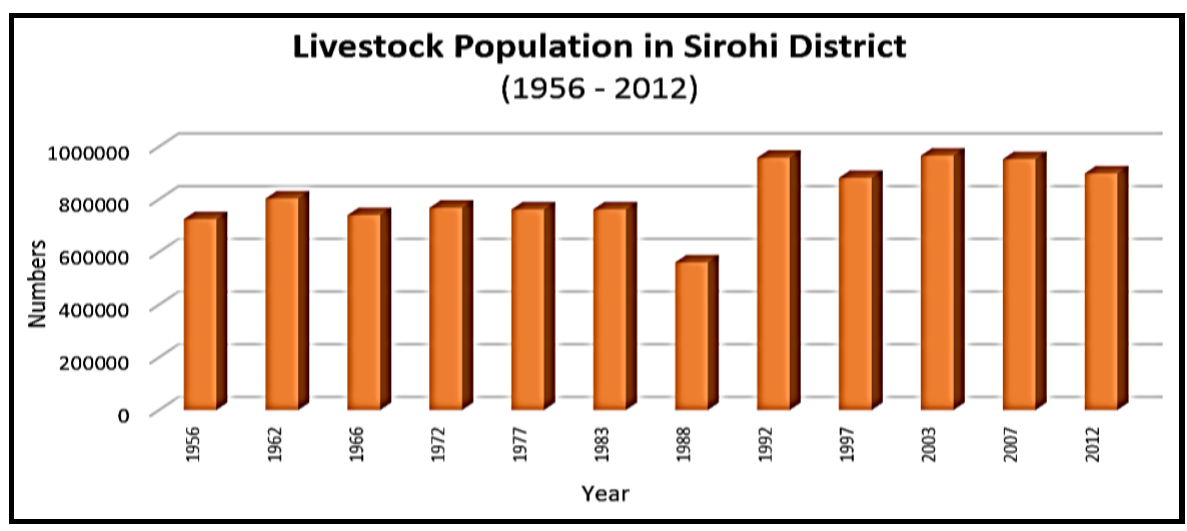


Fig.6 Land capability classes and extent of degradation in Sirohi District

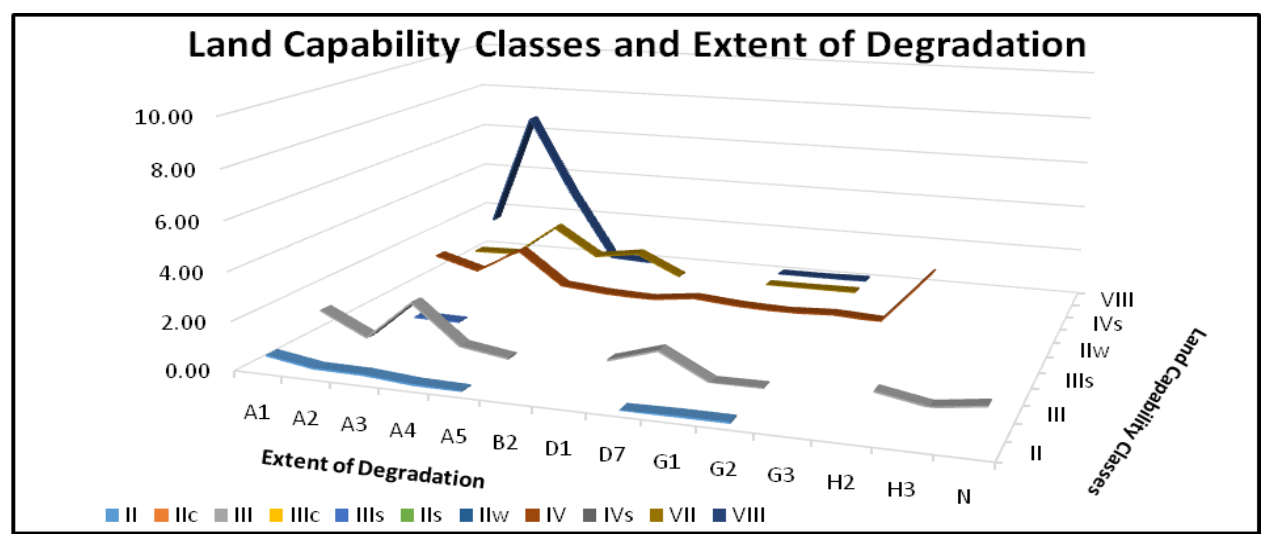

Soils of land class III has moderate physical limitations to arable use that diminish the selection of crops or require extraordinary conservation practices, or sometimes both. Class III land also occurs on shallow and/or stony flats and terraces with low water holding capacities that may also be susceptible to wind erosion. Areas adjacent to water bodies often exhibit moderate kind of erosion (Table 6).

Soils of land class IV have severe physical limitations to arable use. These constraints considerably decrease the range of crops which can be grown, and/or make intensive soil conservation and management essential. This type of land has severe vulnerability to wind erosion, and to sheet, rill and gully erosion and occupies $2.05 \%$ of the total area. Barren rocky/ Stony waste type of rock outcrops/ sheet rock exposures devoid of vegetation occupy $2.31 \%$ of the total area. Erosion is the most common limitation of this category of land. Unfavorable soil characteristics include clay, loamy sand and sand textures, and very stony soils.

Land class VII is highly unsuitable for agricultural use and has severe physical constraints or hazards under permanent vegetation. Hilly zone of Aburoad and Mount Abu area are prone to moderate to severe sheet erosion. It occupies $13.57 \%$ of the total area, of which $2.88 \%$ is comprised of Barren rocky/ Stony waste category with soils of Entisol order. Consequently, it is high-risk land requiring active management to achieve sustainable production. It can be suited to grazing provided intensive soil conservation measures and practices are in place, and in many cases, it is more suitable for forest plantation. Because of the relationships between climate, topography, and soils, more than one of these limiting features is usually present. The limitation is more severe and its versatility is significantly less.

Soils of land class VIII is threatened by very severe to extreme kind of physical limitations or degradations. Thus, it is not suitable for arable, pastoral, or plantation purpose. The most common limitation is extreme actual or potential erosion, often combined with severe climatic and/or soil fertility limitations. Sandy loam to find sand of the order of Entisols is available in this category occupying $31.42 \%$ of the total area. Slight, Moderate and Severe type of sheet erosion occupies $1.49 \%, 6.68 \%$ and $3.15 \%$ area respectively whereas Barren rocky/ Stony waste covers $8.48 \%$ area of the total. This class of land is mainly very steep mountain land although it also includes very steep slopes at low elevations such as deep rills and gully sides and highly degradable areas. 


\section{Suitability for different crops}

The soil and land resources map units of Sirohi district were evaluated for its suitability for growing of different crops and agricultural plantations. The results showed that $0.09 \%$ area of the district is covered by clayey soil, $7.88 \%$ by fine sand, $9.39 \%$ by loamy soil, $8.63 \%$ by loamy sand, $61.21 \%$ by sandy loam and $12.80 \%$ by silt loam soils (Table 7).

The result showed that the areas that are highly suitable for food grains in Kharif season (pearl millet, sorghum, barley and maize growing) $8.88 \%$ area of the district on loamy sand and sandy loam soil. The loamy sand and find sand soils are suitable for kharif pulses like moong bean. Among the Rabi crops, groundnut (1.9), castor (6.11), rape and mustard $(2.27 \%)$, fennel $(1.17 \%)$, cumin $(0.48 \%)$ occupies a sizeable area. Fodder crops occupy an area of $1.09 \%$ of the total district area. Majority of agricultural activities are confined in Sheoganj, Reodar and Sirohi blocks only. An area under barren rocky/ stony waste is predominant in Aburoad and Pindwara blocks of the district where waterborne degradation is quite distinguishable.

\section{Approaches to sustainable livelihoods for the rural people}

Livelihoods approaches are undertaken with people so as to support them to build upon their own strengths through optimal utilization of natural resources.

It helps to develop an accurate and dynamic picture of them in their own environment. About 80 percent population inhabits in rural areas of the district, depending upon 38 percent agricultural land. Sustainable rural development activities may be undertaken for sustenance and income generation.

Degraded Lands and Rural Development:
Fluvial degradation is dominant in all classes of land use affecting $41.9 \%$ area. Gum/resin is exuded by various commonly found trees species in the area like, Acacia Senegal, Acacia tortalis, Anogeissus pendula, Anogeissus rotundifolia, Cordia myxa, Balanitiesaegyptiaca, Prosopis juliflora, Acacia jacquemontii, Acacia nilotica, Prosopis cineraria, Azadirachta indica, Hardwickia binate, etc. These exude gum is a small quantity naturally and collection of gum/resin exudated from trees is important livelihood sources for rural population. CAZRI has developed gum-inducer which helps in the increase of exudation of gum. It fetches a fairly high amount in the market. In this way, their income might be increased. A very high order of adoption of the said technological package in hot arid areas of the country has changed the economies of many poor farmers.

It has been a proven technology that microcatchment lined with LDPE lining has increased Ziziphus nummularia ( ber) fruit yield by $105 \%$. Livelihood system of many farmers has improved and changed in thehot arid region and may be replicated in the Sirohi district.

Stream flow water harvesting anicut/check dam: Check-dams constructed in series are extremely effective for stream flow water harvesting and the harvested rainwater can be used for supplemental irrigation to tree plantation. It will check water erosion and partially reclaim gully through heavy sedimentation behind the structure. It will also induce groundwater recharge. It has been observed that $1.8-4.2 \mathrm{~m}$ annual rise in surface water level and $65 \%$ higher water yield in wells in the zone of influence of anicuts.

Rehabilitation of mined wastelands: Most of the limestone mines follow open-cast mining 
operations and causes the destruction of land resources, viz., denudation of vegetative cover, loss of level and uneven topography, depletion of water resources, poor soil conditions and loss fertile land and soil erosion, etc. Rehabilitation of mined wastelands can be achieved through an optimum combination of rainwater harvesting, soil profile modification and appropriate plant species and a silvipastoral system can complement the animal grazing needs of the local population. Therefore, planting a mixture of trees, shrubs, and grasses for enhancing soil fertility and stability. Suitable species for the district areAcacia catechu, A. nubica, A. Senegal, A. tortilis, Azadirachta indica, Cercidium floridum and Dichrostachys nutans. Even though, native plant species are more successful.

Economy from uneconomic plant resource i.e. $P$. juliflora. It is usually considered an uneconomic plant in rural areas but it does hold a variety of economic value. It does not lose leaves during the long dry season; high nutritional fruits, which are good fodder; it is palatable to almost all species of domestic animals. Village Panchayats regularly auctions a part of the land under its control for its conversion to coal. Produced coal is sold at a higher price in the far and distant cities, thus, earning a good value.

In conclusion the remotely sensed data have been used in the present study to distribution characteristics and assessment of land degradation using different landscape units characterized by land use/ land cover, slope, geomorphology, and land degradation aspect. This methodology allowed us to find out differences in factors supporting land degradation between different landscapes and also to highlight degradation patterns on a very comprehensive level. These maps helped to find out the pattern of land degradation and relating these to pressure indicators like grazing, etc. Analysis of soil, slope, land use/land cover and degradation maps also provided a basis to find out areas suitable for cropping.

\section{References}

Baeza J, Valdecantos A, Alloza JA, and Vallejo RV.( 2007). Human disturbance and environmental factors as drivers of long-term post-fire regeneration patterns in Mediterranean forests. Journal of Vegetation Science, $18(2)$, 243. http://dx.doi.org/10.1658/1100-9233. 18 [243:HDAEFA]2.0.CO;2.

Bai XY, Wang SJ, and Xiong K N. (2013). Assessing spatial-temporal evolution processes of karst rocky desertification land: indications for restoration strategies. Land Degradation and Development, 24(1), 47-56. doi:10.1002/ldr.1102, 2013.

Congalton, RG and Green, K (1999). Assessing the Accuracy of Remotely Sensed Data: Principles and Practices (Boca Raton, FL: CRC/Lewis Press)

Gaur, Mahesh and Sharma, JR (2012) Sustainable Utilization of Wastelands and their economic significance in Western Rajasthan, India. Appeared in: Remote Sensing Application for Dryland Natural Resources Management. NIPA, New Delhi. Pp. 93-116.

Gaur, Mahesh and Sharma, BBL (2003). Desertification and Land Degradation in Arid and Semi-Arid Deserts. (Eds.: Profs. Mary Tahir \& Tahir Hussain). Jawahar, New Delhi. Pp. 26-62.

Gaur, Mahesh and Gaur, H (2003). Impact of Human Activities on Land degradation and Desertification in the Thar Desert - Using Remote Sensing Technique. Appeared in Land Degradation and 
Desertification. V.C. Jha (Ed.), Rawat, Jaipur. Pp. 386-402.

Hao, Chengyuan and Wu, Shaohong (2006). The effects of land-use types and conversions on desertification in $\mathrm{Mu}$ Us Sandy Land of China. Journal of Geographical Sciences, 16(1): 57-68.

Hudson N (1971). Soil Conservation. London: BT Batsford Ltd.

Izzo M, Araujo N, Aucelli PPC, Maratea A, and Sánchez A (2013) Land sensitivity to desertification in the Dominican Republic: an adaptation of the ESA methodology. Land Degradation and Development, 24(5), 486-498. doi:10.1002/ldr.2241, 2013.

Jafari R, and Bakhshandehmehr L. ( 2013). Quantitative mapping and assessment of environmentally sensitive areas to desertification in central Iran. Land Degradation and Development. doi:10.1002/ldr.2227.

Kosmas C, Detsis V, Karamesouti M, Kounalaki K, Vassiliou P, and Salvati L (2015). Exploring long-term impact of grazing management on land degradation in the socio-ecological system of Asteroussia mountains, Greece. Land, 4(3), 541-559. http://dx.doi.org/10.3390/land4030541

Masto RE, Sheik S, Nehru G, Selvi VA, George J, and Ram LC. ( 2015). Assessment of environmental soil quality around Sonepur Bazari mine of Raniganj coalfield, India. Solid Earth, 6(3), 811. doi:10.5194/se-6-811-2015.

Riva, M.J., Daliakopoulos, I.N., Eckert, S., Hodel, E., Liniger, H(2017). Assessment of land degradation in Mediterranean forests and grazing lands using a landscape unit approach and the normalized difference vegetation index. Applied Geography, 86 ( 9), 8-21. https://doi.org/10.1016/j.apgeog.2017.
06.017

Santana VM, Alday JG, and Baeza MJ (2014). Effects of fire regime shift in Mediterranean Basin ecosystems: Changes in soil seed bank composition among functional types. Plant Ecology, 215(5), 555-566. http://dx.doi.org/10.1007/s11258-0140323-1.

Scarascia-Mugnozza G, Oswald H, Piussi P, and Radoglou K. (2000). Forests of the Mediterranean region: Gaps in knowledge and research needs. Forest Ecology and Management, 132(1), 97109. http://dx.doi.org/10.1016/S03781127(00)00383-2.

Scheffer M, Bascompte J, Brock WA, Brovkin V, Carpenter SR, Dakos V, Hermann Held, Egbert H. van Nes, Max Rietkerk, Sugihara G (2009). Early-warning signals for critical transitions. Nature, 461(7260), 53-59. http://dx.doi.org/10.1038/nature08227.

Sen, Hemant and Nagori, M.L. ( 2016). Hydrogeology, groundwater resources and analysis of potential aquifers in Malani Igneous Suite-A case study of Sirohi district of Rajasthan. International Journal of Civil Engineering and Technology (IJCIET), 7(6), pp. 106-114.

Spanos IA, Daskalakou E N, and Thanos CA. (2000). Postfire, natural regeneration of Pinus brutia forests in Thasos Island, Greece. Acta Oecologica, 21(1), 13-20. http://dx.doi.org/10.1016/S1146609X(00)00107-7.

Tewari, V. P. and Arya, Ranjana (2004) Degradation of Arid Rangelands in Thar Desert, India: A Review, Arid Land Research and Management, 19:1, 1-12, DOI: 10.1080/15324980590887056.

Thomas RJ, Quillérou E, Stewart N. (2013). Economics of Land Degradation 
Initiative: A global strategy for sustainable land management in sustainable land management, September 2013, 124. http://inweh.unu.edu/wpcontent/uploads/2013/09/ELD-GlobalStrategy.pdf (Scientific Interim Report of the Economics of Land Degradation, accessed on $10^{\text {th }}$ October, 2017).

Warren, A. ( 2002). Land degradation is contextual. Land Degradation and Development, 13(6), 449e459. http://dx.doi.org/10.1002/ldr.532.

Websites: http://www.cgwb.gov.in/District_Profile/Raja sthan/Jalore.pdf (accessed on $10^{\text {th }} \mathrm{Nov}$ 2017).

http://shodhganga.inflibnet.ac.in/bitstream/10 603/107901/12/12_chapter\%201.pdf (accessed on $10^{\text {th }}$ Nov 2017).

\section{How to cite this article:}

Mahesh Kumar Gaur, Mahesh Kumar, JS Chauhan, Ashish Mishra, Suraj Ismail Sheikh Pragya Mehrishi and Prachi Goyal. 2020. Spatio-Temporal Dynamics of Land Degradation in Rural Areas of Thar Desert of India. Int.J.Curr.Microbiol.App.Sci. 9(12): 1553-1568. doi: https://doi.org/10.20546/ijcmas.2020.912.184 